\title{
Association of Prion Protein with the Stage of Liver Fibrosis in Chronic Viral Hepatitis
}

\author{
Kronik Viral Hepatitde Prion Protein ve Karaciğer Fibrozis Evresi Arasmalaki İlişki \\ Muhammet Cemil SAVAŞ ${ }^{1}$, İran KORUK ${ }^{1}$, Mehmet KORUK ${ }^{1}$, Abdurrahman KADAYIFÇ ${ }^{1}$, İbrahim SARI ${ }^{2}$ \\ ${ }^{1}$ Gaziantep Üniversitesi Tıp Fakültesi, Gastroenteroloji Bilim Dall, ${ }^{2}$ Patoloji Anabilim Dal, Gaziantep
}

Submitted / Başvuru tarihi: 26.02.2009 Accepted / Kabul tarihi: 27.05.2009

Objective: Prion protein (PrP) expresion has previously been demonstrated in activated hepatic stellate cells (HSC), which play a key role in the development of liver fibrosis. In this study, we aimed to investigate the correlation between PrP expression and hepatic inflammation/fibrosis in patients with chronic viral hepatitis $(\mathrm{CVH})$.

Material and Methods: Liver specimens of 40 patients with $\mathrm{CVH}$ and 10 patients with metastatic liver disease having a normal liver architecture as a control group were evaluated. ThePrP staining index was calculated by counting PrP positive cells per microscopic field after immunostaining. Hepatic inflammatory activity and fibrosis scores were evaluated and compared with the number of PrP positive HSC.

Results: Varying degrees of PrP expression were detected in histologic samples of the liver in patients with $\mathrm{CVH}$, whereas no staining was observed in control specimens. It was also detected that the grade of inflammatory activity and stage of liver fibrosis were significantly correlated with PrP staining index $(p=0.0001$ for inflammation and $p=0.005$ for fibrosis).

Conclusions: PrP is a good marker of activated HSC and correlates well with the inflammatory activity and stage of fibrosis in $\mathrm{CVH}$.

Key words: Prion protein; viral hepatitis; liver fibrosis; hepatic stellate cell.
Amaç: Prion protein (PrP) ekspresyonu karaciğer fibrozisinde anahtar rol oynayan karaciğer yıldızsı hücrelerinde gösterilmiştir. Bu çalışmada PrP ekspresyonu ile kronik viral hepatit hastalarındaki hepatik inflamasyon ve fibrosis arasındaki ilişki araştırılmıştır.

Gereç ve Yöntemler: 40 kronik viral hepatit hastasının karaciğer biyopsileri ve kontrol grubu olarak da 10 adet metastatik karaciğer hastalığı nedeniyle opere olan ve normal karaciğer dokusu bulunan hastaların biyopsileri çalışmaya alındı. İmmün boyama sonrası PrP boyanma indeksi her mikroskopik alandaki PrP pozitif hücreler sayılarak hesaplandı. Hepatik inflamatuvar aktivite ve fibrozis skorları ile PrP pozitif hücre sayısı arasındaki ilişki karşılaştırldı.

Bulgular: Kronik viral hepatit hastalarının karaciğerlerinde değişik oranlarda PrP ekspresyonu saptanırken, kontrol grupta hiç boyanma gözlenmedi. Ayrıca PrP boyanma indeksi ile kronik hepatit inflamatuvar aktivite derecesi ve fibrozis evresi arasında anlamlı bir korelasyon bulundu (inflamasyon için $p=0.0001$, fibrozis için $\mathrm{p}=0.005)$.

Sonuç: PrP aktivitesi karaciğer yıldızsı hücrelerinin bir belirleyicisidir. Ayrıca PrP boyanmasının kronik viral hepatit hastalarında karaciğer inflamasyonu ve fibrozisi ile iyi bir korelasyonu mevcuttur.

Anahtar sözcükler: Prion protein; viral hepatit; karaciğer fibrozis; karaciğer yıldızsı hücre.

Correspondence (iletişim adresi): Dr. Muhammet Cemil Savaş. Gaziantep Üniversitesi Tıp Fakültesi, Gastroenteroloji Bilim Dalı, Gaziantep, Turkey Tel:0342 3600753 e-mail (e-posta):mcsavas@gmail.com

(- Trakya Üniversitesi Tıp Fakültesi Dergisi. AVES Yayıncılık tarafından basılmıștır. Her hakkı sakılıır.

๑ Medical Journal of Trakya University. Published by AVES Publishing. All rights reserved. 


\section{INTRODUCTION}

Prion protein $(\mathrm{PrP})$ is a glycosylated cell-surface protein which is predominantly expressed in the neurons and glia of the central nervous system. Although the exact function of $\operatorname{PrP}$ could not been elucidated, some studies suggest that it has a role in synaptic transmission, protection against oxidative stress and copper binding. ${ }^{[1]} \mathrm{PrP}$ is a distinctive, transmissible infectious protein with no detectable associated nucleic acids. $\operatorname{PrP}$ is the causative agent of ultimately fatal neurodegenerative diseases called transmissible spongioform encephalopathies of humans (such as Kuru and CreutzfeldtJacob disease) and of animals (scrapie in sheep, bovine spongioform encephalopathy in cattles). Histologically, all of these diseases are characterized by accumulation of insoluble aggregates of fibrillary PrP and spongioform vacuolation of the brain. $\mathrm{PrP}$ is an unconventional infectious agent with respect to the features of extreme resistance to inactivation, causing no humoral or inflammatory response during the course of the disease. A noninfectious form of PrP is present in normal mammalian brains on the surface of neurons and glial cells. It is also expressed in other tissues such as the stomach, kidney, spleen, leucocytes, macrophages and platelets. The function of noninfectious PrP is unknown, but it is suggested to be related to cellular response to oxidative stress, copper binding and synaptic transmission. The conversion of $\operatorname{PrP}$ into a transmissible infectious protein form, which is also known as scrapie PrP, has been thought to be involved in a number of human and animal neurodegenerative diseases such as spongioform encephalopathies. ${ }^{[2-5]}$

Hepatic stellate cells (HSC), together with sinusoidal endothelial cells, constitute the wall of the liver sinusoids, and activation of these cells has a central role in the development of liver fibrosis. ${ }^{[6]}$ Therefore, the determination of HSC activation is important in recognizing the liver fibrosis in an early and potentially reversible stage. Alpha-smooth muscle actin (ASMA), neural cell adhesion molecule (N-CAM), nestin and synapthophysin have been previously reported as markers of HSC activation. ${ }^{[7,8]}$ In addition to these markers, $\operatorname{PrP}$ has been suggested as a novel marker of activated HSC in animal and human studies..$^{[9,10]}$ In the first human study, the number of PrP-positive cells correlated well with the grade of hepatic inflammation but not with the stage of fibrosis in patients with chronic hepatitis. ${ }^{[10]}$ However, this result has not been confirmed by other studies. This study aimed: (i) to confirm the role of $\operatorname{PrP}$ in HSC activation and (ii) to clarify the association of PrP-positive HSC with the stage of fibrosis in patients with chronic viral hepatitis $(\mathrm{CVH})$.

\section{MATERIAL AND METHODS}

Liver specimens, collected and diagnosed at the Pathology Department of Our University between 2004-2007 years, were evaluated retrospectively. Forty patients with $\mathrm{CVH}$ due to hepatitis $\mathrm{B}(\mathrm{n}=33)$ and hepatitis $C(n=7)$, and 10 patients with liver metastasis having normal liver architecture in histologic sections and without chronic liver disease as a control group, were selected from the archives of the Pathology Department. Demographic and clinical characteristics of the study groups were noted (Table 1).

All of the materials were fixed in $10 \%$ formalin solution, embedded in paraffin blocks, and stained by hemotoxylin and eosin routinely. Monoclonal primary antibodies against PrP, ASMA, LSAB kit and diaminobenzidin tetrahydrochloride $(\mathrm{DAB})$ chromogen were obtained from DAKO (Glostrup, Denmark). The primary antibody to PrP was diluted to 1:100. The ASMA was in a prediluted form. The sections were incubated with primary antibody to $\operatorname{PrP}$ overnight at $4^{\circ} \mathrm{C}$ and were incubated with primary antibody to ASMA for $20 \mathrm{~min}$ at room temperature. Then, they were treated with methanol containing $0.003 \%$ hydrogen peroxide for $20 \mathrm{~min}$ at room temperature to inhibit endogenous peroxidase activity. $\mathrm{DAB}$ was used for the peroxidase activity. In the following reactions, a DAKO LSAB kit was used according to to the manufacturer's instructions. After rinsing with phosphate-buffered saline, sections were incubated with biotinylated secondary antibody for $30 \mathrm{~min}$ at room temperature, followed by treatment with peroxidase-conjugated streptavidin for $20 \mathrm{~min}$. Serum diluted 1:100 was used as a control. Counterstaining for nuclei was performed with hematoxylin.

Immunohistochemistry results were semiquantitatively evaluated. PrP positive sinusoidal lining cells (stellate cells) were counted in the liver parenchyma under light microscopy and expressed as the "staining index" for the number of activated stellate cell per microscopic field at the magnification of $\times 200$. At least three fields were randomly selected for each specimen. The areas with large vascular structures were excluded. Staining index was defined based on the following criteria: No expression of stellate cells was named as grade 0 ; 1-5 PrP positive stellate cells as grade 1; 6-10 cells as grade 2; 11-20 cells as grade 3; 21-40 cells as grade 4 . Liver specimens were scored for hepatic inflammatory activity (HIA) and liver fibrosis according to the Desmet classification. ${ }^{[11]}$

Table 1. Demographic and clinical characteristics of patients and $n$ controls

\begin{tabular}{lccc}
\hline & $\begin{array}{c}\text { Chronic B } \\
\text { Hepatitis }\end{array}$ & $\begin{array}{c}\text { Chronic C } \\
\text { Hepatitis }\end{array}$ & Control \\
\hline Number (n) & 33 & 7 & 10 \\
Age (years) & $42(20-59)$ & $54(27-67)$ & $47(22-63)$ \\
Sex (M/F) & $20 / 13$ & $4 / 3$ & $6 / 4$ \\
AST (U/l) & $55(43-179)$ & $59(47-138)$ & $29(17-43)$ \\
ALT (U/l) & $67(48-208)$ & $71(52-196)$ & $25(18-39)$ \\
Albumin (g/dl) & $4.0(3.3-5.6)$ & $3.9(3.5-5.0)$ & $4.1(3.4-5.2)$ \\
T. Biluribin (mg/dl) & $0.8(0.7-1.3)$ & $1.0(0.7-1.5)$ & $0.9(0.6-1.1)$ \\
& & &
\end{tabular}


The Mann-Whitney U-test and Sperman's rank correlation test were used for statistical analysis. A $p$ value $<0.05$ was considered as significant.

\section{RESULTS}

$\operatorname{PrP}$ expression in varying intensities was detected in all specimens of liver with $\mathrm{CVH}$, whereas no expression was found in controls (Fig. 1a). PrP stainings were present not only in the sinusoidal lining cells within the lobules but also in mesenchymal cells in expanded portal tracts. PrP expression of stellate cells along the sinusoids was intensely stained adjacent to the piecemeal and spotty necrosis and prominent lymphocyte infiltration. Spindle shaped cells in the fibrosis septa and in the expanded fibrous portal areas also exhibited positive staining for $\operatorname{PrP}$.

According to semi-quantitative evaluation defined as the staining index, 11 out of 40 cases $(27.5 \%)$ had grade 1, $10(25 \%)$ had grade 2, $8(20 \%)$ had grade 3, 11 (27.5\%) had grade 4 staining for PrP.

According to the Desmet classification: 7 patients $(17.5 \%)$ had minimal, 14 patients $(35 \%)$ had mild, 12 patients $(30 \%)$ had moderate and 7 patients $(17.5 \%)$ had severe HIA. For the staging of fibrosis, there were 2 patients (5\%) with no fibrosis, $8(20 \%)$ with minimal, 12 $(30 \%)$ with mild, $9(22.5 \%)$ with moderate and $9(22.5 \%)$ with severe fibrosis.

Minimal staining index was seen in chronic hepatitis with minimal HIA and no fibrosis. The PrPpositive sinusoidal lining cells were found increased in parenchyma of liver with mild HIA and mild fibrosis (Fig. 1b). Moreover, in chronic hepatitis with moderate activity and moderate fibrosis, PrP-positive sinusoidal lining cells increased considerably in number in the liver parenchyma (Fig. 1c). In chronic hepatitis with early stage of cirrhosis, a small number of PrP-positive cells were seen in the expanding septa as well as in the sinusoidal lining cells in residual liver parenchyma.

The comparison of PrP expression with the ASMA, a well-recognized marker for stellate cell activation, revealed that ASMA-positive cells showed similar staining patterns and intralobular location as the PrP-positive cells in $\mathrm{CVH}$, except that vascular smooth muscle cells were also stained for ASMA.

In the correlation analysis of the intensity of the PrP staining cells to the histologic activity and fibrosis of liver, the grade of $\mathrm{PrP}$-positive cell correlated significantly with HIA of liver ( $r=0.730, p=0.0001)$ (Fig. 2) and stage of liver fibrosis ( $\mathrm{r}=0.434, \mathrm{p}=0.005)$ (Fig. 3).

\section{DISCUSSION}

This study confirms the expression of $\operatorname{PrP}$ in the activated HSC of patients with CVH. Similar to the study of Kitada et al, a significant staining was detected in patients with $\mathrm{CVH}$, while normal livers were negative for PrP. ${ }^{[10]}$ Our study clearly showed that $\mathrm{PrP}$ is a marker of activated HSC in chronic liver injury. In addition, a significant correlation between PrP expression and the HIA was also detected in our study, confirming the previous study. ${ }^{[10]}$ Moreover, a significant correlation was also been shown for the first time between the staining index of PrP-positive HSC and the stage of liver fibrosis. Since correlation coefficient $r=0.434, p=0.005$, the relation is statistically significant but not a strong one. We believe this finding indicates the importance of PrP-positive HSC in the pathological conditions of active inflammation and also fibrosis of liver. In spite of an overall correlation between PrP-positive cell number and stage of fibrosis, a slight decrease in the number of positive HSC in severe fibrosis was observed compared to moderate stage of fibrosis in the current study. This might be due to advanced distortion of liver cells and sinusoids by extensive fibrosis. A similar finding of a decrease of labeling index of PrP-positive stellate cells in severe fibrosis and cirrhosis was also detected in the study of Kitada et al. ${ }^{[10]}$

Although we could not perform an immuno-electron microscopy imaging in this study, the expression of $\operatorname{PrP}$ was also correlated with that of ASMA, which is a well known marker for HSC activation. This finding, together with the previous reports, revealed that the stained cells were activated HSC. ${ }^{[10]}$ The presence of PrP in activated
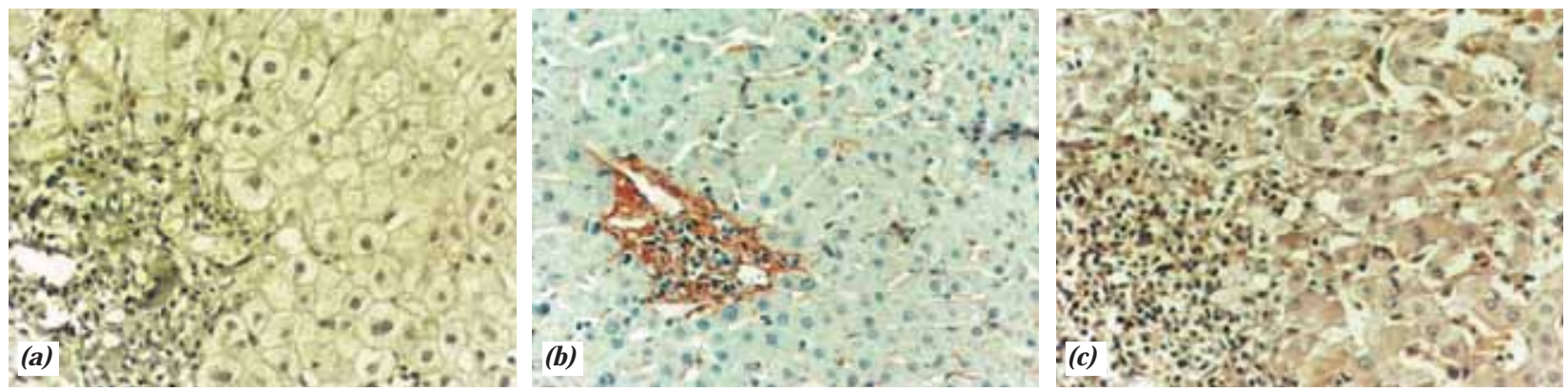

Figure 1. Demostration of PrP-positive cells in normal liver specimens and liver specimens of chronic viral hepatitis, 1a. Grade 0 PrP reactivity; no $\operatorname{PrP}$ positive stellate cell was seen in portal area and sinusoidal areas in normal liver ( $x 400), 1 b$. Grade 2 PrP reactivity; PrP positive stellate cells were seen in portal area and sinusoids (x400), 1c. Grade 4 PrP reactivity; PrP positive stellate cells were profusely seen in sinusoids ( $x 400)$. 


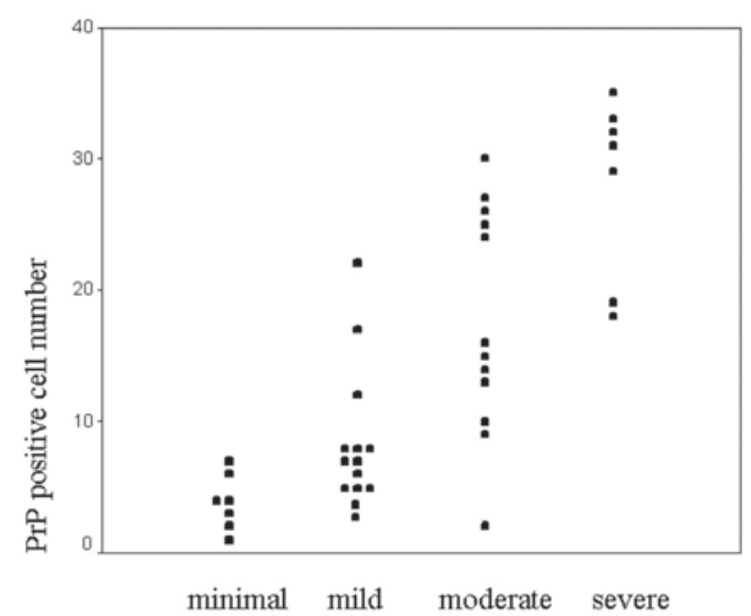

Figure 2. PrP expression in CVH was graded by HIA. The number of PrP-positive cells correlated with the severity of inflammatory activity.

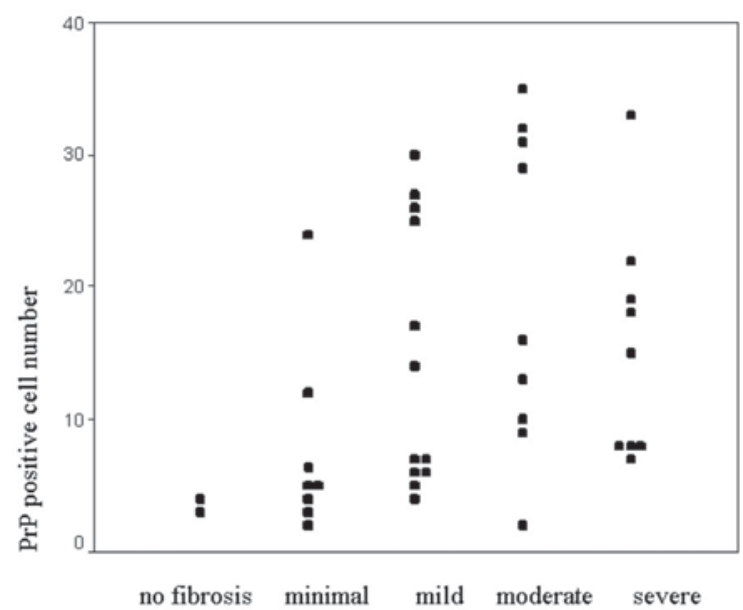

Figure 3. PrP expression in $\mathrm{CVH}$ graded by stage of liver fibrosis. The level of PrP expression correlated with the stage of liver fibrosis.

HSC provided an additional marker to stain these cells in histological sections and it shed light on the pathogenesis of liver fibrosis.

The questions why activated HSC express PrP, which is normally present mainly in the central nervous system, and the function of $\operatorname{PrP}$ are obscure at present. It was thought that HSC were of mesenchymal origin. However, in recent years, several lines of evidence have suggested that HSC are of neuro-ectodermal origin. The physiological function of PrP is not known exactly, but several reports suggested a role for PrP in oxidative homeostasis. PrP binds copper, and internalizes it into the cytoplasm. Since many antioxidant enzymes depend on copper and the main stimulus for activation of quiescent HSC is oxidative stress, expression of $\operatorname{PrP}$ on activated HSC may function in cellular response to oxidative stress. $^{[1,12-14]}$

Chronic liver injury of any kind activates the normally quiescent HSC to undergo transdifferentiation into activated myofibroblast-like cells. Activated HSC are characterized by excessive collogen synthesis, decreased release of matrix metalloproteinases that degrade collagen and increased expression of physiological inhibitors of metalloproteinases. Excessive accumulation of extracellular matrix as a consequence of HSC activation eventually leads to liver fibrosis and progressive loss of liver function. ${ }^{[15,16]}$ It is not clear at present whether PrP is only a simple marker of activated HSC and severity of HIA as well as fibrosis, or has any role in the pathophysiology of hepatic fibrogenesis.

In conclusion, we established in the current study that $\operatorname{PrP}$ is a good marker for activated HSC in CVH. The number of PrP-positive cells correlated well with the degree of hepatic inflammation and stage of fibrosis reflecting disease activity in chronic liver disease. If further studies support these findings, it would be a potential marker for early determination and follow-up of the stage of fibrosis in liver.

\section{Conflict of Interest}

No conflict of interest declared by the authors.

\section{REFERENCES}

1. Reyneart H, Burt A, Geerts A: Prions in activated hepatic stellate cells: not a suprise after all. J Hepatol 2000;33:838-41.

2. Harman JL, Silva CJ. Bovine Spongioform Encephalopathies. J Am Vet Med Assoc 2009;234:59-72.

3. Fournier JG, Escaig-Haye F, Billette de Villemeur T, Robain O, Lasmézas CI, Deslys JP, et al. Distribution and submicroscopic immunugold localisation of cellular prion protein $(\mathrm{PrPc})$ in extracerebral tissue. Cell Tissue Res 1998;292:77-84.

4. Askanas V, Sarkozi E, Bilak M, Alvarez RB, Engel WK. Human muscle macrophages express beta-amyloid precursor and prion protein and their mRNAs. Nueroreport 1995;6:1045-9.

5. Perini F, Vidal R, Ghetti B, Tagliavini F, Frangione B, Prelli F. PrP 27-30 is a normal solubl prion protein fragment released by human platelets. Biochem Biophys Res Commun 1996;223:572-7.

6. Friedman SL. Mechanisms of Hepatic Fibrogenesis. Gastroenterology 2008;134:1655-69.

7. Nakatani K, Seki S, Kawada N, Kobayashi K, Kaneda K. Expression of neural cell adhesion molecule (N-CAM) in perisinusoidal stellate cells of the human liver. Cell Tissue Res 1996;283:159-65.

8. Cassiman D, van Pelt J, De Vos R, Van Lommel F, Desmet V, Yap SH, et al. Synaptophysin: a novel marker for human and rat hepatic stellate cells. Am J Pathol 1999;155:1831-9.

9. Ikeda A, Kawada N, Wang YQ, et al. Expression of cellular prion protein in activated hepatic stellate cells. Am J Pathol 1998;153:1695-700. 
10. Kitada T, Seki S, Ikeda K, Nakatani K, Sakaguchi H, Kawada N, et al. Clinicopathological characterization of prion: a novel marker of activated human hepatic stellate cells. J Hepatol 2000;33:751-7.

11. Desmet VJ, Gerber M, Hoofnagle JH, Manns M, Scheuer PJ. Classification of chronic hepatitis: diagnosis, grading and staging. Hepatology 1994;19:1513-20.

12. Pauly PC, Harris DA. Copper stimulates endocytosis of prion protein. J Biol Chem 1998;273:33107-10.

13. Miele G, Jeffrey M, Turnbull D, Manson J, Clinton M. Ablation of cellular prion protein expression affects mitochondrial numbers and morphology. Biochem Biophys Res Commun 2002;291:372-7.

14. Klamt F, Dal-Pizzol F, Conte da Frota ML Jr, Walz R, Andrades ME, da Silva EG, et al. Imbalance of antioxidant defense in mice lacking cellular prion protein. Free Radic Biol Med 2001;30:1137-44.

15. Reeves HL, Friedman SL. Activation of hepatic stellate cells--a key issue in liver fibrosis. Front Biosci 2002;7:808-26.

16. Savas MC. Pathogenesis of Hepatic Fibrosis. Turkiye Klinikleri J Int Med Sci 2005; 1:5-10. 